\title{
Pengaruh Penggunaan Sistem Isyarat dalam Program Berita Seputar inews Siang RCTI terhadap Tingkat Pemahaman pada Penyandang Tunarungu Di Gerkatin Kota Bandung
}

\section{The Effect of The Use of Sign Language in The RCTI "Seputar iNews Siang" News Program on The Deaf Level of Understanding in Gerkatin Bandung}

\author{
Shafira Albari*, Idola Perdini Putri
}

Telkom University, Jl Telekomunikasi 1, Buah Batu, Bandung 40257, Indonesia

${ }^{*}$ E-mail: albarishafira12@gmail.com

Diterima: 10 Juni 2020 | Disetujui: 24 Maret 2020 | Publikasi online: 06 Mei 2021

\section{ABSTRACT}

This study aims to determine the influence of the system of sign language in a news program "Seputar iNews Siang" in a private Indonesia channel, on the level of understanding among deaf. The study was conducted on deaf people from a disabilities movement and organization called Gerkatin, Bandung. The averaged ages of informant is 20-30 years old and they have watched and are fond with the news program studies. In this study, the authors apply descriptive quantitative research methods with the correlation approach significantly influenced the understanding level of people with hearing loss with a percentage of $65.7 \%$ and $r_{\text {count }}$ of $1.307>r_{\text {table }}$ of 1.984 translation states that HO is rejected and $H 1$ is accepted. In variable $X$ this research is included in the good category, with the results of the percentage score of $79.23 \%$ and the $Y$ presentation variable of $85.73 \%$ which is included in the very good category. The total population is 250 people. This article applied a purposive sample technique and obtained a sample size of 30 people. The results of the study showed that the use of the system of sign language in "Seputar iNews Siang"is effective". This shows that the level of understanding of deaf people is sufficient.

Keywords: deaf people, disabilities, mass media, non-governmental organization, sign language

\begin{abstract}
ABSTRAK
Penelitian ini bertujuan untuk mengetahui bagaimana pengaruh penggunaan komponen penunjang dan penentu Sistem Isyarat dalam program berita Seputar iNews Siang RCTI terhadap tingkat pemahaman pada penyandang tunarungu di Gerkatin kota Bandung. Penelitian dilakukan pada penyandang tunarungu di Gerkatin kota Bandung. Informan diketahui gemar dan pernah menonton siaran berita di Seputar iNews Siang RCTI yang rata-rata berusia 20-30 tahun. Pada penelitian ini, penulis menggunakan metode penelitian kuantitatif deskriptif dengan pendekatan korelasi. Populasinya adalah penyandang tunarungu/teman tuli di Gerkatin (Gerakan untuk Kesejahteraan Tuli Indonesia) Kota Bandung dengan total populasi sebanyak 250 orang. Peneliti menerapkan teknik purposive sample dengan jumlah sampel sejumlah 30 orang. Hasil dari penelitian ini menunjukkan pengaruh penggunaan sistem isyarat dalam program berita Seputar iNews Siang RCTI pada penyandang tunarungu di Gerkatin kota Bandung adalah efektif dengan jumlah presentase sebesar $65,7 \%$ dengan $r_{\text {hitung }}$ sebesar 1,307 $>r_{\text {tabel }}$ 1,984. Maka dapat disimpulkan dari penjabaran tersebut bahwa H0 ditolak dan $\mathrm{H} 1$ diterima. Pada variabel X penelitian ini termasuk ke dalam kategori baik, dengan hasil skor presentase sebesar $\mathbf{7 9 , 2 3 \%}$ dan presentase variabel Y sebesar $\mathbf{8 5 , 7 3 \%}$ yang masuk ke dalam kategori sangat baik. Hal ini memperlihatkan bahwa tingkat pemahaman penyandang tunarungu sudah cukup memahami lewat menerjemahkan, menafsirkan, dan mengekstrapolasi.
\end{abstract}

Kata kunci: tuna rungu, disabilitas, media massa, organisasi non pemerintah, sistem isyarat

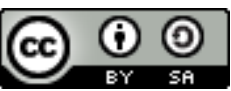




\section{PENDAHULUAN}

Informasi kini menjadi begitu krusial agar seluruh aspek kehidupan bisa diketahui. Informasi bisa terperoleh lewat penghimpunan data atau fakta yang sudah terolah dan terkelola hingga akhirnya menjadi hal yang berfaedah. Tidak semua data informasi ini bisa dijadikan informasi bagi pembacanya. Bila suatu data itu tidak memberi kemanfaatan bagi pembacanya maka informasinya belum bisa dianggap informasi. Hampir semua televisi di Indonesia menyajikan program berita, dalam kenyataannya saat ini penyandang tunarungu masih sukar memperoleh informasi yang tersiarkan. Kurangnya interpreter (penerjemah) bahasa isyarat untuk tunarungu yang ingin mendengarkan berita. Setiap masyarakat memiliki hak yang sama yaitu mendapatkan informasi yang layak. Tetapi, bagaimana halnya dengan masyarakat yang sedikit informasi seperti penyandang tunarungu yang memiliki keterbatasan fisik mengenai pendengaran sehingga di haruskan orang khusus untuk dapat memahami hal tersebut. Susanto (2010) mengungkapkan bahwa masyarakat pada macam beragam membutuhkan dan sangat mengharapkan hidup yang berkehidupan secara wajar, tentram, damai dan berkeadilan. Dalam kebutuhan tersebut hanya dapat digapai ketika semua peran masyarakat yang memiliki kepastian dan juga pengakuan tentang hak yang didapat sesuai dengan peran dan fungsinya di tempat masyarakat tersebut hidup. Harapan pada setiap masyarakat untuk membentuk norma-norma yang berlaku. Namun, pada kenyataan yang kini dihadapi pada praktiknya belum ditemukan.

Anwas, Sumardjo, Asngari, \& Tjitropranoto (2009) menyatakan bahwa butuh seseorang untuk menjadi penyuluh sebagai fasilitator dalam mengembangkan sistem penerjemah ini. Fasilitator tersebut dituntut untuk dapat menyesuaikan dengan perubahan hingga tuntutan demi menjadi masyarakat yang terus berkembang. Berikutnya, definisi cara kerja pesan bukan lisan yakni mengaplikasikan alat bantu lain di luar alat kebahasaan (Sendajaja, 2005:227-228). Sebagaimana yang dipaparkan (Budyatna dan Ganiem, 2011:110), komunikasi non verbal mencakup pengkomunikasian tiap keterangan atau emosi yang diterapkan lewat kata-kata (non linguistik).

Namun fenomena yang terjadi dalam hal memahami aksesibilitas informasi televisi masih rendah terhadap kebutuhan penyandang tunarungu. Fenomena tersebut meliputi belum tersedianya akses sarana informasi dan komunikasi terhadap penyandang tunarungu pada media. Belum adanya pergerakan cara bagaimana untuk pemenuhan hak informasi dan komunikasi bagi penyandang tunarungu. Sampai saat ini, ada beberapa stasiun televisi yang masih menggunakan interpreter bahasa isyarat dalam siaran beritanya antara lain SCTV, TVRI, RCTI, CNN, NET TV, Kompas TV, Trans TV dan TvOne (dikutip dari kompasiana.com pada pukul 20.33 WIB (22/01)). Dikutip dari kpi.go.id, RCTI kini menjadi program berita nomer satu di Indonesia pada akhir tahun 2019. Salah satu konten berita yaitu Seputar Indonesia kini berganti nama menjadi Seputar iNews Siang di mana ada fitur penerjemah bahasa isyarat yang disajikan pada program beritanya yang bernama Seputar iNews Siang.

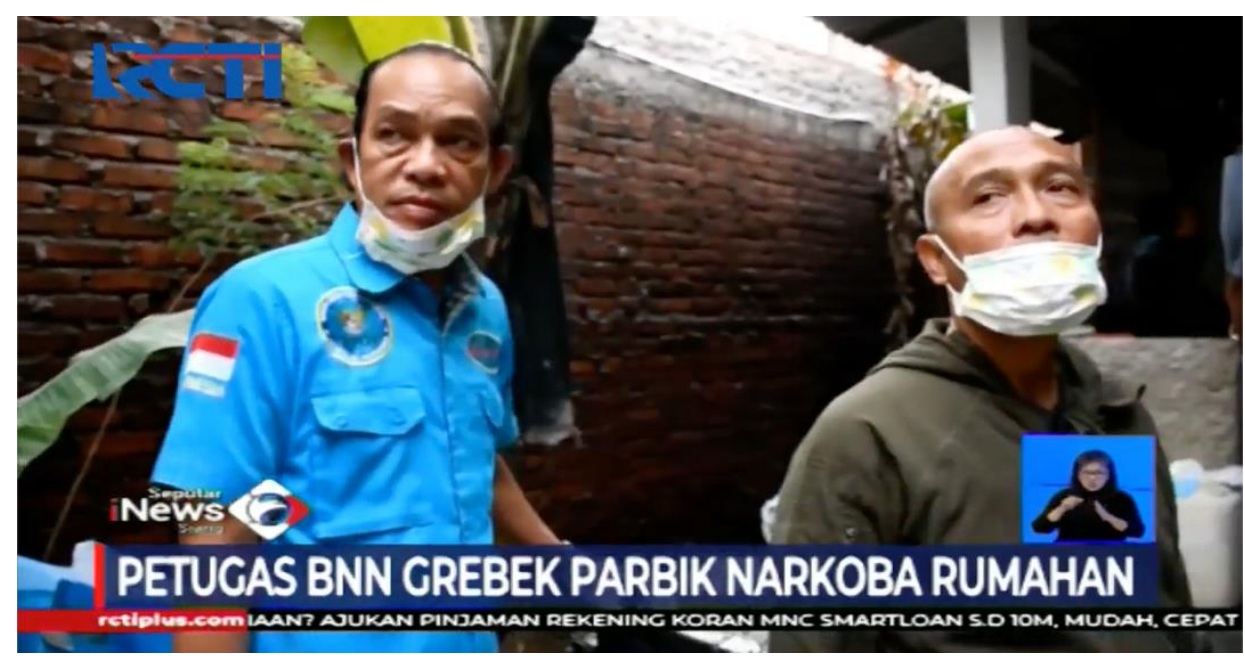

Gambar 1. Potongan Gambar dari Video Program Berita Seputar iNews Siang di RCTI

Pada siaran berita tersebut, Seputar iNews Siang RCTI menggunakan interpreter bahasa isyarat agar penyandang tunarungu bisa memperoleh informasinya dengan gampang. Penelitian yg dilakukan Arianti, Saleh, Priatna, \& Komunikasi (2015) keikutsertaan pada khalayak dalam menentukan apa yang akan 
dilihat dari media massa kini sangat dibutuhkan, mengingat khalayak terbuka dalam memilih media. Menurut Maulia (2017) meskipun penggunaan interpreter masih minim digunakan oleh para stasiun televisi, Rajawali Citra Televisi (RCTI) adalah salah satu televisi nasional yang memberikan fasilitas berupa penerjemah bahasa isyarat melalui tayangan beritanya. Adapun kolom untuk penerjemah yang berada di layar kanan bawah diperuntukan bagi penyandang tunarungu. Dalam istilah bahasa isyarat di Indonesia terdapat 2 jenis, yaitu Sistem Isyarat Bahasa Indonesia (SIBI) dan Bahasa Isyarat Indonesia (BISINDO). SIBI bahasa isyarat dibuat langsung oleh pemerintah tanpa melibatkan penyandang tunarungu dan proses pemyampaian pesannya lewat bahasa Indonesia lisan. Pembuatannya yaitu dengan diubahnya bahasa Indonesia lisan menjadi gerakan isyarat. Pesan nonverbal berperan sebagai perantara yang terakurat dalam hal memersuasi (Rakhmat, 2005:287). Komunikasi nonverbal ialah komunikasi yang dijalankan dengan melibatkan wajah, isyarat, nada suara, kontak mata dan sebagainya. Penyampaian dengan verbal diperkuat oleh pesan non verbal (Liliweri, 20019:140). Terlihat pada proses pandangan hidup untuk menjadi lebih maju, pengembangan dapat diartikan sebagai proses logis akal masyarakat yang terlibat terhadap nilai-nilai yang dimiliki oleh negara-negara berkembang, seperti masih menggunakan cara lama dalam mengatasi berbagai permasalahan kehidupan yang masyarakat alami (Rusadi, 2014). Penyandang tunarungu menggunakan sebuah sistem isyarat tangan yang komprehensif, oleh karena itu bisa menjadi substitusi bahasa lisan secara literal (Tubbs dan Moss, 2008:137).

Badan Pusat Statistik, SAKERNAS 2016 menyampaikan, jumlah penyandang disabilitas di Indonesia yaitu $12 \%$ dari total penduduk, sementara menurut Pusat Data dan Statistik Pendidikan dan Kebudayaan, Kemendikbud RI tahun 2017 penyandang tuli jumlahnya 24.374 jiwa, yakni posisinya ada di peringkat kedua setelah tunagrahita.

Menurut detikNews (2014) Gerkatin menyampaikan rasa terima kasih kepada KPU dan stasiun TV yang telah memberi akses informasi bagi penyandang tunarungu. Namun pihak Gerkatin memberi saran agar kotak penerjemah bahasa isyarat tersebut diperbesar. Gerkatin adalah sebuah organisasi sosial yang berisikan teman-teman tuli untuk memperjuangkan hak-hak disabilitasnya. Di tahun 2019, penyandang tunarungu dari usia balita hingga lansia jumlahnya kisaran 6 juta orang. Sejak tahun 1960-an, perkumpulan tunarungu di kota Bandung sudah didirikan oleh penyandang tunarungu alumni SLB-B Bandung dan Wonosobo.

Gerkatin itu sendiri merupakan organisasi satu-satunya yang berdiri di Indonesia. Seluruh pengorganisasiannya dikelola oleh penyandang tunarungu. Makna dari kata "Gerakan" sebagai jiwa dari penyandang tunarungu yang dijalankan niatnya untuk memperjuangkan hak mereka. Fokus keorganisasian ini meliputi, bidang pendidikan, pengembangan BISINDO (Bahasa Isyarat Indonesia), hubungan masyarakat, kesehatan, kesenian \& kebudayaan, tenaga kerja, kepemudaan \& olahraga, dan kewanitaan.

Menurut penjelasan Pasal 4 ayat (1) huruf di UU No. 8 Tahun 2016 tentang Penyandang Disabilitas, tunarungu termasuk pada jenis penyandang Disabilitas Sensorik. Dalam pasal tersebut dijelaskan bahwa tunarungu ialah seseorang yang mempunyai hambatan dalam pendengaran baik secara permanen maupun tidak permanen. Hambatan dalam pendengaran tersebut meyebabkan tunarungu juga memiliki hambatan dalam hal berbicara.

Seperti yang disebutkan pasal di atas, informasi berhak didapatkan penyandang tunarungu. Oleh karena itu, memberikan kemudahan bagi penyandang disabilitas dalam hak memperoleh informasi yang diperuntukkan bagi tunarungu dengan SIBI di mana munculnya bahasa SIBI juga tidak lepas dari hak tunarungu untuk mendapatkan informasi, termasuk informasi dari televisi. Pada situs ayobandung.com keterbatasan yang dilibatkan oleh teman tuli sendiri bukan halangan untuk mereka berkarya. Bukti tersebut dikarenakan banyaknya teman-teman tunarungu Gerkatin Jawa Barat yang bisa mengajar bahasa isyarat dan membuat banyak karya, seperti kaos dan juga topi "kita pengennya Teman Tuli (sebutan Gerkatin untuk penyandang tunarungu) bisa dilihat sama masyarakat kalua mereka punya karya dan bermanfaat bagi orang lain".

Menkominfo memiliki rencana agar semua acara televisi memberikan layanan dengan menggunakan bahasa isyarat. Ini menunjukan karena kebijakan bahasa isyarat yang terdapat di TV dalam revisi UU penyiaran. Dikutip dari kominfo.go.id pada pukul 12.31 WIB (20/09), pihak Menteri Komunikasi dan Informasi, Rudiantara memberi stimulus agar stasiun televisi menyediakan saluran komunikasi sebagai opsi supaya disabilitas bisa tertampung. Contohnya yaitu running text. Hal ini masih di fase perancangan yang secepatnya dijalankan sebab tidak sedikit pengeluaran biaya produksinya. 
Kewajiban pada penyiaran yang nantinya diwajibkan ialah pemakaian bahasa isyarat di program berita. Lewat kebijakan ini, penyandang tunarungu bisa berkesempatan paham akan apa yang dirasakan orang normal sebab mereka akan bisa merasakannya pula. Menurut Herdiansah \& Randi (2016), pemerintah harus dapat menyetarakan proses pembangunan yang dapat memberikan manfaat demi rakyat.

Pada situs kominfo.go.id, Rudi sungguh mengekspektasikan implementasi kebijakan bahasa isyarat itu bagi penyandang disabilitas. Hal ini mendalat dukungan dari dua rekannya yakni anak bungsu dari Dewi Yuli dan Ray Sahetapy, termasuk dari ketua GERKATIN kota Solo Aprillian Bima Purnama perihal impelementasi kebijakan dalam pemakaian bahasa isyarat.

Pada situs bbc.com, Lynn Stewart-Taylor penyandang tunarungu Amerika Serikat mengatakan hak penyandang disabilitas di negara tersebut belum dipenuhi secara utuh, Pada saat penayangan berita ia bisa merasakan informasi yang sedang ditayangkan tersebut adalah penting namun tidak terdapat penerjemah sehingga, pada 9 Maret Lynn Stewart-Taylor menge-tweet \#WhereIsTheInterpreter? Sementara pengakuan dari beberapa penerjemah telah menganggap bahwa running text yang telah disediakan sudah cukup untuk orang tuli mendapatkan informasi. Kurangnya penerjemah BSL (British Sign Language) membuat penyandang disabilitas di Amerika Serikat tersebut merasa sangat panik dan khawatir tidak mendapatkan informasi.

Pada penelitian terdahulu, menggunakan pendekatan kualitatif deskriptif. Teori yang digunakan pada penelitian tersebut menggunakan teori uses and gratification. Teknik pengumpulan data yang diperoleh pada penelitian ini dengan cara wawancara dan observasi. Didapati bahwa tidak ada keefektifan pada hasil penelitian tersebut para penyandang tunarungu disebabkan karena penelitiannya tidak memenuhi lima indikator yang peneliti gunakan dalam mengidentifikasi efektivitas pemakaian BISINDO. Penelitian Zuhir \& Amri (2019) mengindikasikan, dari ulasan hasil analisisnya ditemukan bahwa kebutuhan informasi penyandang tunarungu di Kota Banda Aceh belum bisa terpenuhi pada implementasi BISINDO. Penelitian ini menunjukkan bahwa terdapat lima indikator yang diteliti yaitu, kebutuhan kognitif, kebutuhan afektif, kebutuhan integrasi personal, kebutuhan integrasi sosial, dan kebutuhan berkhayal tidak memenuhi terhadap para penyandang tunarungu. Penyandang tunarungu Banda Aceh pada saat itu tidak memahami secara keseluruhan Bahasa Isyarat Indonesia (BISINDO) yang diterapkan stasiun televisi, namun mereka lebih memahami Sistem Isyarat Bahasa Indonesia (SIBI).

Penelitian lainnya, Pratiwi \& Amri (2019) mengenai penggunaan Sistem Isyarat Bahasa Indonesia (SIBI) sebagai media komunikasi mengungkapkan siswa tunarungu memiliki pandangan berbeda tentang pembelajaran Sistem Isyarat Bahasa Indonesia (SIBI). Beberapa dari siswa yang telah diwawancarai beranggapan SIBI merepotkan karena terlalu formal. Terbatasnya bahasa yang digunakan menyebabkan sulitnya memaknai sebuah pesan. Teori pada penelitian ini menggunakan teori interaksi simbolik. Berdasarkan latar belakang dan fokus penelitian, maka identifikasi masalah yang diambil adalah "Bagaimana pengaruh penggunaan komponen penunjang dan penentu Sistem Isyarat dalam program berita Seputar iNews Siang RCTI terhadap tingkat pemahaman pada penyandang tunarungu di Gerkatin kota Bandung?"

\section{METODE}

Pada penelitian ini, penulis mengaplikasikan metode penelitian kuantitatif deskriptif. Metode ini bisa didasarkan pada metode penelitian yang acuannya ada pada filsafat positivisme yang bisa diterapkan dalam mengobservasi sampel dan populasi (Sugiyono, 2015:8). Penelitian ini memilih unit analisis individu, dimana data terkait variabel yang digunakan didapatkan dari setiap individu yang ada pada organisasi dan berdasarkan waktu pelaksanaan, penelitian ini menggunakan teknik skala likert, dimana pengumpulan data dilakukan sekali sesuai waktu yang telah ditentukan (Suharsaputra, 2012:39).

Paradigma pada penelitian ini mengaplikasikan penelitian korelasi, yakni studi yang penelitiannya studi yang penelitiannya mengaitkan aktivitas pengambilan data guna menentukan, apakah adanya kaitan antara variabel satu ke variabel lainnya. Penelitian korelasi ini tujuannya yaitu agar bisa menemukan ada tidaknya hubungan tersebut.

Populasi ialah semua data akan menjadi ketertarikan kita dalam suatu bagian dan waktu yang sudah kita tetapkan (Margono, 2004:118). Maksudnya, populasi bersinggungan dengan data, bukannya objeknya. Populasi pada penelitian ini ialah penyandang tunarungu di Gerkatin Kota Bandung. Total populasinya yaitu 250, sementara data yang peneliti peroleh di organisasi Gerkatin jumlahnya 250 orang. 
Perihal penetapan jumlah sampel yang akan diteliti, penulis mengaplikasikan teknik penarikan sampel. Teknik purposive sampling, yakni pengambilan sampelnya didasarkan pada kriteria khusus sudah peneliti buat sesuai tujuan penelitian lewat disebarkannya kuesioner pada responden yaitu penyandang tunarungu atau teman tuli di Gerkatin Kota Bandung.

Jumlah sampel pertama yang diteliti yaitu 30 responden. Hal ini selaras dengan apa yang disampaikan Singarimbun dan Efendi (1995) yakni jumlah responden pertama yang terteliti pada uji coba kuesioner ialah setidaknya 30 partisipan. Dari 30 orang ini, distribusi nilainya akan mendekati kurve normal.

Pengumpulan data pada penelitian ini dijalankan lewat pendistribusian kuesioner. Kuesioner ialah teknik menghimpun data yang penulis lakukan lewat pengajuan pertanyaan online pada responden. Kuesioner yang disebarkan ini dijalankan sebab keefektifan teknik pengumpulan datanya. Data yang terhimpun dari kuesioner bisa penulis peroleh lewat pendistribusian kuesioner, yakni diwujudkan dalam Google form.

Alat ukur untuk mengidentifikasi variabel yang peneliti aplikasikan pada penelitian ialah korelasi Pearson Product Moment yang mengukur signifikasi antara satu variabel dengan variabel lainnya. Untuk pengukuran instrumen dari kuesioner, sampel awal yang peneliti ambil jumlahnya 30 responden. Nilai $\mathrm{r}_{\text {tabel }}$ dengan tingkat signifikan sebanyak $5 \%$ dan $\mathrm{N}=30$ terperoleh nilai $\mathrm{r}_{\text {tabel }}$ sebesar 0,306 . Berikut tabel hasil uji validitas terhadap 30 responden awal tersebut. Korelasi Product Moment ialah teknik pencarian korelasi antara dua variabel yang kerap diaplikasikan. Korelasi Pearson ini difungsikan sebagai alat uji statistik dalam uji hipotesis asosiatif (uji hubungan) dua variabel bila datanya berskala rasio. Teknik korelasi ini pengembangnya yaitu Karl Pearson.

Sutoyo (2012:55), memberi penjelasan bahwasanya uji validitas diterapkan agar bisa mengidentifikasi valid tidaknya butir pertanyaan. Hasil uji validitas pada angket penelitian ini harus membandingkan antara angka korelasi item dengan total korelasi yang terperoleh dengan angka $r$ butir $>r$ tabel (Ghozali, 2013:45). Dikarenakan angka korelasi yang terperoleh dari pertanyaan pada indikator 1-18 posisinya melebihi angka 0,361, maka pertanyaan itu signifikan dan validitasnya bagus.

Reliabilitas ialah standar konsistensi responden dalam menjawab hal yang ada keterkaitannya dengan pertanyaan yang menjadi dimensi variabel dan penyusunannya dalam wujud kuesioner. Bila pengukurannya dijalankan $2 \mathrm{x}$ atau lebih pada gejala yang sama dan alat ukurnya pun sama. Metode yang penulis gunakan pada penelitian ini yaitu metode Cronbach's Alpha, yakni sebuah ukuran keandalan yang nilainya berkisar dari nol hingga satu (Hair et al., 2010: 92).

Sesuai dengan penghitungan uji reliabilitas yang sudah penulis lakukan, ditemukan bahwa variabel X yang mengaplikasikan metode Cronbach alpha melebihi 0,7 yaitu 0,904. Maka dapat disimpulkan bahwa instrument yang digunakan tergolong konsisten dan reliabel.

Analisis deskriptif diterapkan agar bisa memberi penggambaran data yang terhimpun dari kuesioner mengenai tanggapan responden perihal efektivitas komunikasi interpersonal terhadap kepuasan pelanggan. Bentuk kuesioner yang diaplikasikan pada penelitian ini ialah kuesioner tertutup, yakni kuesioner yang jawabannya sudah ada, kemudian responden tinggal memilihnya (Arikunto, 2010:195).

Penentuan predikat setiap itemnya akan membantu penulis dalam meneliti item mana yang mendapatkan nilai sangat rendah, rendah, tinggi dan sangat tinggi pada masing-masing variabelnya. Terdapat empat kategori penilaian, yaitu sangat setuju, setuju, tidak setuju dan sangat tidak setuju. Maka dapat dicermati jika responden memberi nilai 4 , berarti nilai pernyataan tersebut tergolong sangat tinggi. Jika responden memberi nilai 3, berarti nilai pernyataannya tergolong tinggi, bila nilai 2 yang diberikan, berarti nilai pernyataannya rendah dan jika nilainya 1 , berarti nilai pernyataannya tergolong sangat rendah. Hipotesis ialah jawaban sementara dari rumusan masalah penelitian. Dianggap sementara sebab perolehan hasilnya supaya dilakukan pengujian secara empiris. Oleh karena itu, rumusan masalah penelitian umumnya penyusunannya berbentuk kalimat pertanyaan (Sugiyono, 2018:99).

Hipotesis dalam penelitian ini adalah sebagai berikut:

$\mathrm{H}_{0}$ : Tidak terdapat pengaruh penggunaan Sistem Isyarat pada program berita Seputar iNews Siang RCTI terhadap tingkat pemahaman bagi penyandang tunarungu.

$\mathrm{H}_{1}$ : Terdapat pengaruh penggunaan Sistem Isyarat pada program berita Seputar iNews Siang RCTI terhadap tingkat pemahaman bagi penyandang tunarungu. 


\section{HASIL DAN PEMBAHASAN}

Penelitian ini sejatinya bertujuan untuk menganalisis pengaruh penggunaan sistem isyarat pada program berita Seputar iNews Siang RCTI terhadap tingkat pemahaman penyandang tunarungu di Gerkatin kota Bandung. Responden yang diteliti sebanyak 80 orang, rinciannya yaitu responden laki-laki jumlahnya 46 orang dan perempuan jumlahnya 34 orang. Adapun usia responden yang peneliti dapatkan pada usia 10 hingga 20 tahun sebanyak 7 orang, usia 21 hingga 30 tahun sebanyak 49 responden dan 30 hingga 40 tahun sebanyak 24 responden. Usia 21 hingga 30 tahun menjadi responden terbanyak sebab memang ratarata responden penyandang tunarungu yang menonton tv. Saat berlangsungnya proses pengumpulan data, peneliti menyebarkan kuesioner via aplikasi chat yakni Whatsapp yang pada saat itu peneliti langsung mengontak langsung ketua Gerkatin kota Bandung untuk meminta tolong dalam penyebaran link google form ke group organisasi yang telah ada.
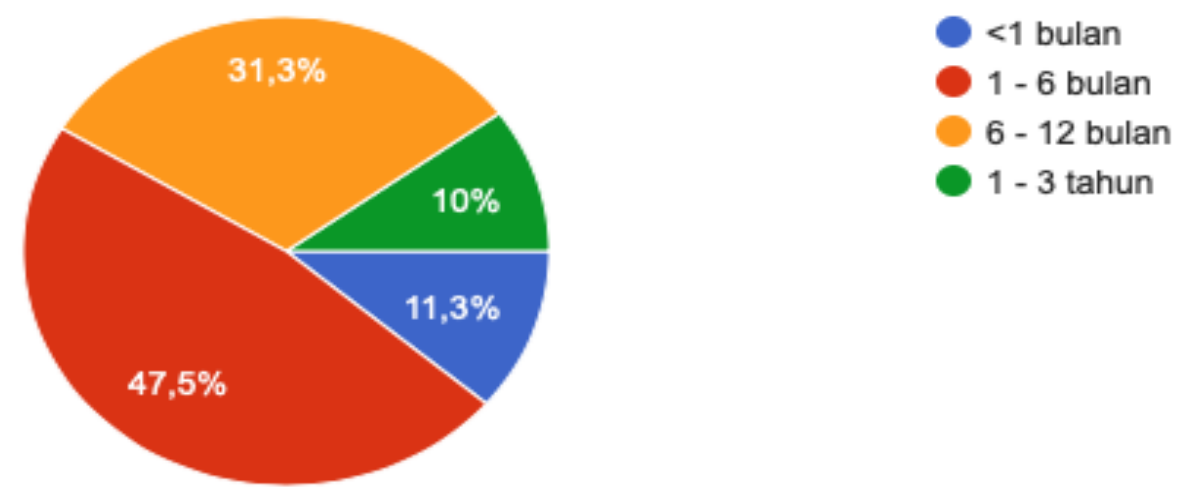

Gambar 2. Karakteristik Responden Berdasarkan Lama Waktu Menonton

Sebagaimana yang ditampilkan gambar diatas, bisa diamati bahwasanya dari 80 responden yang diteliti, sebesar 100\% yang sudah menonton tayangan berita Seputar iNews Siang RCTI kurang dari 1-3 Tahun, sebesar 11,3\% diantaranya telah menonton tayangan berita Seputar iNews Siang RCTI selama kurang dari 1 bulan, sebesar 31,3\% diantaranya sudah menonton tayangan berita Seputar iNews Siang RCTI selama 6 - 12 bulan, dan sebesar 47,5\% diantaranya telah menonton tayangan berita Seputar iNews Siang RCTI diantara $1-6$ bulan. Hal ini menadakan bahwasanya kebanyakan responden pada penelitian ini sudah menonton tayangan berita Seputar iNews Siang RCTI selama 1 sampai 6 bulan lamanya.

Sebelum bisa melanjutkan ke fase penelitian selanjutnya, diperlukan uji validitas dan uji reliabilitas, agar bisa diketahui bahwa data tersebut dikategorikan valid dan reliabel untuk diaplikasikan. Sebagaimana hasil perhitungan uji validitas dan reliabilitas yang dijalankan peneliti mengaplikasikan SPSS 17, ditemukan fakta bahwa seluruh item pernyataan yang peneliti sebar tergolong valid. Totalnya yaitu 32 pernyataan yang disebarkan kepada responden, seluruhnya punya koefisien validitas ( $\mathrm{r}$ hitung) yang melebihi batas kritis ( $\mathrm{r}$ tabel) yang ditentukan yakni 0,361. Hal ini mengindikasi bahwa keseluruhan item pernyataan dianggap valid, oleh karenanya layak menjalankan penelitian ke tahap berikutnya.

\section{Variabel X}

Pada tahap uji t, terperoleh nilai t hitung sebesar 13,078. Dikarenakan t hitung melebihi t tabel $(1,984)$, maka H0 ditolak. Interpretasinya, terdapat pengaruh penggunaan Sistem Isyarat Terhadap Tingkat Pemahaman Pada Penyandang Tunarungu. Untuk mengetahui lebih jelasnya, berikut dijelaskan mengenai pada variabel Penggunaan Sistem Isyarat (X).

\section{Komponen Penentu}

Dari hasil tanggapan responden terhadap dimensi komponen penentu ini presentase menunjukan 80,10\% untuk 10 butir pernyataan yang penulis sebarkan ke responden. Artinya, hasil presentase menunjukan bahwa interpretasi pada dimensi ini tergolong sangat tinggi. Hal ini menunjukan bahwa penampilan, posisi, tempat, arah, dan juga frekuensi tersebut dinilai bahwa penyandang tunarungu menilai pesan yang 
disajikan penerjemah tersebut terbilang sudah sangat baik.

\section{Komponen Penunjang}

Dari hasil tanggapan responden terhadap dimensi komponen penunjang ini presentase menunjukan $78,55 \%$ untuk 8 butir pernyataan yang penulis sebarkan ke responden. Artinya, hasil presentase menunjukkan bahwa interpretasi pada dimensi ini tergolong baik. Hal ini menunjukkan mimik muka, gerak tubuh, kecepatan dan kelenturan gerak yang diperagakan oleh interpreter tersebut terbilang sudah baik. Artinya, hasil presentase menunjukkan bahwa interpretasi pada sub variabel ini termasuk tinggi. Hal ini menunjukkan bahwa penyandang tunarungu menilai interpreter (penerjemah) sistem isyarat pada program berita sudah cukup jelas namun dengan kecepatan gerak yang terlalu cepat.

\section{Variabel Y}

Secara keseluruhan tanggapan responden pada variabel ini sebesar 79,23\% untuk 18 item pernyataan, hasil ini termasuk dalam kategori baik. Artinya variabel ini terbilang cukup jelas saat penerjemah menerjemahkan kata perkata. untuk mengetahui lebih jelas lagi, berikut dijelaskan mengenai dimensi pada variabel Tingkat Pemahaman Penyandang Tunarungu (Y) dalam penelitian ini.

\section{Menerjemahkan}

Menerjemahkan bisa dimaksudkan dengan pengubahan arti dari makna satu ke makna yang lain. Mudah diartikan juga dari rancangan yang abstrak menjadi suatu model yang dapat dimaknakan untuk mempermudah seseorang yang mempelajarinya. berdasarkan hasil tanggapan responden terhadap sub variabel menerjemahkan ini presentase menunjukan $85,62 \%$ untuk 4 item pernyataan yang penulis sebarkan kepada responden. Hal ini menunjukan bahwa sub variabel ini berkategori sangat baik. Interpretasinya, penerjemah yang melakukan penerjemahan sudah sangat baik.

\section{Menafsirkan}

Menafsirkan dapat digambarkan sebagai suatu keahlian untuk mengetahui dan mengartikan. Menafsirkan diperoleh sebagai bentuk yang mengaitkan pengetahuan dengan pengetahuan yang lainnya, mengaitkan tersebut antara grafik dengan konteks yang dijabarkan, beserta membedakan antara yang pokok dan yang tidak pokok. Dari hasil tanggapan responden terhadap sub variabel menafsirkan ini presentase menunjukkan $87,06 \%$ untuk 5 item pernyataan yang penulis sebarkan kepada responden. Hal tersebut menunjukan bahwa sub variabel ini masuk ke dalam kategori sangat baik. Interpretasinya, penyandang tunarungu memperoleh informasi baru lewat tayangan berita, serta bisa membedakan pesan antara yang pokok dan yang tidak pokok.

\section{Mengekstrapolasi}

Ekstrapolasi bisa dijabarkan sebagai kemampuan intelektual yang lebih tinggi sebab seseorang didesak agar bisa mencermati hal yang terimplikasi dari suatu bentuk tulisan. Dari hasil tanggapan responden terhadap sub variabel mengekstrapolasi ini presentase menunjukan $85,43 \%$ untuk 5 item pernyataan yang penulis sebarkan kepada responden. Kesimpulannya, penyandang tunarungu bisa mengerti masalah yang terdapat di berita tersebut.

Secara keseluruhan tanggapan responden pada variabel ini sebesar 85,73\% untuk 14 item pernyataan, hasil tersebut termasuk ke dalam kategori sangat baik. Artinya penyandang tunarungu memahami apa yang di sampaikan interpreter (penerjemah). Hasil analisis regresi linier sederhana yang dijalankan peneliti menjelaskan bahwasanya variabel pengaruh penggunaan sistem isyarat berpengaruh secara signifikan dengan arah sangat baik terhadap variabel tingkat pemahaman penyandang tunarungu dengan jumlah presentasenya sebesar $65,7 \%$. Maka dapat disimpulkan bahwa penggunaan sistem isyarat berpengaruh sangat baik terhadap pemahaman penyandang tunarungu. Untuk sisanya yang sebesar 33,3\% dipengaruhi faktor-faktor lain yang tak didukung penelitian ini. Pada uji hipotesis didapatkan hasil bahwa adanya pengaruh penggunaan sistem isyarat pada program berita terhadap tingkat pemahaman penyandang tunarungu bisa diamati dari hasil hipotesis tersebut yaitu, rhitung sebesar 12,225> dari rtabel 1,984, penjabaran tersebut menyatakan $\mathrm{H} 0$ ditolak dan $\mathrm{H} 1$ diterima. 


\section{Pengaruh Variabel X dan Y}

Hasil analisis regresi linier sederhana dalam penelitian ini menunjukkan bahwa variabel pengaruh yaitu penggunaan sistem isyarat berpengaruh secara signifikan dengan arah sangat baik terhadap variabel tingkat pemahaman penyandang tunarungu dengan jumlah presentasenya yaitu 65,7\%. Maka dapat disimpulkan bahwa penggunaan sistem isyarat pengaruhnya sangat baik terhadap pemahaman penyandang tunarungu. Untuk sisanya yang sebesar 33,3\% terpengaruhi oleh faktor-faktor lain yang tidak didukung oleh penelitian ini. Pada uji hipotesis didapatkan hasil, adanya pengaruh penggunaan sistem isyarat pada program berita terhadap tingkat pemahaman penyandang tunarungu dapat dilihat dari hasil hipotesis tersebut yaitu, $\mathrm{r}_{\text {hitung }}$ sebesar 1,307 > dari $\mathrm{r}_{\text {tabel }} 1,984$, penjabaran tersebut menyatakan $\mathrm{H} 0$ ditolak dan H1 diterima.

Dalam teori SOR, pada proses berjalannya stimulus (pesan) dari pembawa pesan (komunikator) kepada penerima pesan (komunikan) dimana proses pernyampaian berita tersebut berjalan satu arah atau one way communication oleh karena itu seorang individu bisa mengekspektasikan dan memprediksi kecocokkan antara keterangan dan responsnya komunikan (Effendy 2003:254). Bila sudah ada atensi terhadap stimulus tersebut telah diterima, maka komunikan paham pada proses tersebut. Kemudian, komunikan akan memproses stimulusnya yang pada tahap akhir tersebut bersedia untuk ia terima. Efek pesan dari pembawa pesan (komunikator) melalui media massa timbul pada komunikan sebagai sasaran komunikasi. Pada konteks penelitian ini, seorang tunarungu diekspektasikan bisa mempunyai pemahaman atas apa yang sudah ia pelajari, agar apa yang dikomunikasikan bisa diketahui, serta keterangan yang didapatkan bisa dimanfaatkan dengan memadai tanpa mengaitkan sesuatu yang lain.

Sehingga dari hasil perhitungan keseluruhan dari penelitian ini, maka kesimpulannya ialah pengaruh penggunaan sistem isyarat pada program berita terhadap tingkat pemahaman penyandang tunarungu sudah cukup baik. Hal ini menandakan tingkat pemahaman penyandang tunarungu sudah cukup memahami lewat menerjemahkan, menafsirkan, dan mengekstrapolasi.

\section{KESIMPULAN}

Pengaruh penggunaan sistem isyarat dalam program berita Seputar iNews Siang RCTI Pada variabel X penelitian ini tanggapan responden secara keseluruhan berkategori baik, di mana hasil skor presentasenya yaitu $79,23 \%$. Hal ini mengindikasikan, penggunaan sistem isyarat dalam program berita termasuk cukup baik untuk melakukan penambahan informasi. Presentase variabel Y yaitu terhadap tingkat pemahaman penyandang tunarungu secara keseluruhan memperoleh skor presentase $85,73 \%$ yang berkategori sangat baik. Hal ini menandakan pesan yang disampaikan interpreter pada penyandang tunarungu sudah sangat baik.

Dari hasil analisis korelasi terdapat hubungan antara pengaruh penggunaan sistem isyarat dalam program berita terhadap penyandang tunarungu sebesar 0,811 . Interpretasinya, ada hubungan yang sangat kuat antara variabel X dan Y. Sebab posisinya ada di interval korelasi 0,80 sampai dengan 1,000. Apabila nilai $\mathrm{R}$ (koefisien korelasi) dimasukkan ke dalam persamaan koefisien determinasi, maka hasil yang didapat yaitu $65,7 \%$. Dengan ini sebesar $65,7 \%$ penggunaan sistem isyarat dalam program berita Seputar iNews Siang RCTI dipengaruhi oleh tingkat pemahaman penyandang tunarungu dan 33,3\% terpengaruhi oleh faktor-faktor lainnya. Hasil analisis regresi linear sederhana terhadap variabel Y pada penelitian ini menunjukkan hasil yang positif yaitu $\mathrm{Y}=1,307+0,573 \mathrm{X}$ maka asumsinya yaitu kedua variabel berhubungan searah, yakni bilamana variabel X tinggi maka variabel Y pun akan tinggi.

Hipotesis ialah eksplanasi yang bersifat temporer mengenai peristiwa tertentu yang sudah muncul atau akan muncul (Kurniawan, 2014:57). Pada uji hipotesis didapatkan hasil adanya pengaruh penggunaan sistem isyarat dalam program berita terhadap tingkat pemahaman penyandang tunarungu yang bisa dilihat hasil hipotesisnya yaitu, rhitung sebesar 1,308 > dari rtabel 1,984, penjabaran tersebut menyatakan H0 ditolak dan $\mathrm{H} 1$ diterima.

Hasil keseluruhan pada penelitian ini ialah ada pengaruh penggunaan sistem isyarat dalam program berita terhadap tingkat pemahaman di kota Bandung. Pengaruh yang cukup signifikan dalam pengaruh penggunaan sistem isyarat yang berdampak baik pada penyandang tunarungu di Gerkatin kota Bandung. 
Pada variabel $\mathrm{X}$ sistem isyarat yang meliputi 2 komponen yaitu komponen penentu dan komponen penunjang pada komponen penentu, meliputi Penampil, yakni bagian tangan yang dimanfaatkan dalam pembentukan isyarat yang diperagakan oleh penerjemah sudah cukup baik. Posisi, yakni letaknya tangan terhadap pengisyarat pada saat mengisyarat sudah baik. Tempat, yakni bagian tubuh yang posisinya sebagai spot utama pembentukan atau arah akhir isyarat pada hasil ini para penyandang tunarungu mengatakan kolom yang berisikan penerjemah tersebut masih terlalu kecil bentuknya sehingga perlu di perbesar kembali. Arah, yakni gerakan yang ditunjukkan penampil pada saat pembuatan isyarat sudah cukup baik. Frekuensi, yakni jumlahnya gerakan tatkala pembentukan isyarat sudah baik. Kemudian ada komponen penunjang yang meliputi mimik muka, gerak tubuh misalnya, bahu dan tangan, kecepatan serta kelenturan gerak. Dalam kecepatan gerak, dan kelenturan gerak yang didapat pada hasil penelitian ini, adanya gerakan yang terlalu cepat yang dilakukan oleh penerjemah sehingga para penyandang tunarungu masih keliru untuk menanggapi informasi yang ada di berita tersebut.

Saran yang dapat diberikan untuk stasiun televisi yang menggunakan interpreter (penerjemah). Selain menampilkan informasi yang akurat dan faktual, kolom yang berisikan penerjemah agar diperbesar lagi sehingga informasinya bisa dipahami para penyandang tunarungu. Di samping itu, untuk kecepatan gerak tangan, penerjemah melakukannya dengam pelan agar penyandang tunarungu bisa memahami informasi yang disampaikan secara gampang. Mereka pun tidak sekadar bisa menerjemahkan dan menafsirkan tetapi juga bisa mengekstrapolasikan informasi yang disampaikan, yang akhirnya mereka bisa memberi pandangan perihal apa yang sudah diterimanya. Untuk stasiun-stasiun TV yang belum menggunakan penerjemah dalam program beritanya, diharapkan segera untuk dilakukan agar seluruh masyarakat mendapatkan hak dan kewajibannya. Disarankan bahwa penelitian ini dapat menjadi acuan bagi peneliti selanjutnya yang akan menggunakan teori SOR namun diharapkan dengan objek yang berbeda dengan menggunakan stasiun televisi lainnya. Selain itu, peneliti selanjutnya dapat menggunakan informan yang lebih beragam dengan jangkauan yang luas.

\section{UCAPAN TERIMAKASIH}

Penulis menyampaikan terimakasih untuk ketua Gerkatin Bandung dan teman-teman tuli di Gerkatin yang telah mengasisteni penulis mengumpulkan data, serta untuk orang-orang istimewa yang telah membantu penulis untuk menyempurnakan penelitian ini.

\section{DAFTAR PUSTAKA}

Anwas, E., Sumardjo, S., Asngari, P., \& Tjitropranoto, P. (2009). Faktor-Faktor yang Mempengaruhi Penyuluh dalam Pemanfaatan Media. Jurnal Komunikasi Pembangunan, 7(2), 69-81.

Arianti, G., Saleh, A., Priatna, W. B., \& Komunikasi, P. K. (2015). Persepsi pembaca tentang berita pembangunan di surat kabar radar bogor. Jurnal Komunikasi Pembangunan, 13(1), 1-11.

Arikunto, Suharsimi. (2010). Prosedur Penelitian Suatu Pendekatan Praktek. Jakarta: Rineka Cipta.

Dellanita, Anya. 2019. Berita Mengenai Penyandang Tunarungu. [Internet] [Diakses 10 April 2020] https://ayobandung.com/read/2019/03/24/47834/gerkatin-jabar-ajarkan-bahasa-isyarat-gratis

Depdiknas, (2002). Kamus Sistem Isyarat Bahasa Indonesia. Jakarta: Direktorak PLB.

Detik News. 2014. Berita Mengenai Penyandang Tunarungu. [Internet]. [diakses 15 Februari 2020] https://news.detik.com/berita/d-2617689/penyandang-tunarungu-harap-kotak-penerjemah-di-layartv-lebih-besar?r771108bcj=\&r771108bcj=

Dina, Steffani. 2017. Kementerian Komunikasi dan Informatika Republik Indonesia. [Internet]. [diakses 10 September2019] https://kominfo.go.id/content/detail/11557/penggunaan-bahasa-isyarat-di-acaratelevisi-akan-diwajibkan/0/sorotan media

Gerkatin. 2014. Visi dan Misi Gerkatin. [Internet]. [diakses 2 November 2019] https://gerkatinsolo.or.id/tentang-kami/visi-misi/ 
Ghozali, Imam. 2013. Aplikasi Analisis Multivariate dengan Program IBM SPSS

21 Update PLS Regresi. Semarang: Badan Penerbit Universitas

Diponegoro.

Hair, Jr et.al. (2010). Multivariate Data Analysis (7th ed). United States ,: Pearson

Herdiansah, A. G., \& Randi. (2016). Peran Organisasi Masyarakat (Ormas) dan LSM dalam Menopang Pembangunan di Indonesia. Socioglobal: Jurnal Pemikiran Dan Penelitian Sosiologi, 1(1), 49-67.

Margono, 2004, Metodologi Penelitian Pendidikan, Jakarta: Rineka Cipta

Maulia, N. (2017). Pengaruh Penggunaan Sistem Isyarat Bahasa (SIBI) terhadap Pemahaman Informasi Siswa Penyandang Tunarungu di SLB-PKK Provinsi Lampung. Jurnal MetaKom, 1(1), 81-95.

McQuail, Denis. 2011. Teori Komunikasi Massa McQuail. Jakarta: Salemba Humanika.

Nurudin. 2011. Pengantar Komunikasi Massa. Jakarta: Raja Grafindo Persada.

Pratiwi, A., \& Amri, A. (2019). Penggunaan Sistem Isyarat Bahasa Indonesia (SIBI) sebagai Media Komunikasi (studi pada siswa tunarungu di SLB Yayasan Bukesra Ulee Kareng, Banda Aceh). Jurnal Ilmiah Mahasiswa FISIP Unsyiah, 4(3), 1-12.

Riduwan \& Kuncoro. 2012. Cara Menggunakan dan Memakai Path Analysis (Analisis Jalur).

Bandung: Alfabeta.

Rusadi, Udi (2014). Makna dan Model Komunikasi Pembangunan. Jurnal pada Mitra Bestari.

Singarimbun, M dan Efendi,. (1995), Metode penelitian survey, Jakarta: PT. Pustaka LP3ES

Sugiyono (2015). Metode Penelitian Kuantitatif dan R\&D. Bandung:Alfabeta.

Susanto, D. (2010). Strategi Peningkatan Kapasitas Modal Sosial dan Kualitas Sumberdaya Manusia Pendamping Pengembangan Masyarakat. Jurnal Komunikasi Pembangunan, 8(1), 77-89. https://doi.org/10.29244/jurnalkmp.8.1.\%p

Suharsaputra, Uhar. 2012. Metode Penelitian: Kuantitatif, Kualitatif dan Tindakan. Bandung: PT. Refika Aditama

Sujarweni, V. W., \& Endrayanto, P. (2012). Statistika Untuk Penelitian. Yogyakarta: Graha Ilmu.

Youtube. 2019. Cuplikan Video tentang Kolom Perjemah. [Internet]. [Diakses 20 Januari 2020] https://www.youtube.com/watch?v=dHOdhBoGLqE\&list=PLM_DxXIRzXJxTYbvBeo6ELEY2Edi wQigR\&index $=4$

Zuhir, J., \& Amri, A. (2019). Penggunaan Bahasa Isyarat Indonesia (BISINDO) pada Siaran Berita dalam Pemenuhan Kebutuhan Informasi Penyandang Tunarungu di Kota Banda Aceh. Jurnal Ilmiah Mahasiswa FISIP Unsyiah, 4(3), 1-15. 